muscles, and in the soles of pounding feet. The slightly increased blood loss in stools seems to be of no clinical importance in most athletes, ${ }^{9}$ but we should be cautious because of sporadic cases of excessive faecal blood loss associated with marathon training. ${ }^{10-12}$ Some of these cases, particularly those accompanied by abdominal pain, vomiting, or frank blood in the stools, need investigation as in any patient. Sometimes a sinister cause will be found. Often the bleeding may be the result of the athlete taking analgesics before the race, ${ }^{12-14} \mathrm{a}$ practice that should be condemned.

Athletes in training do not thus need any routine clinical or haematological monitoring or any iron supplementation. The athletes and others who are at risk of iron deficiency anaemia include those with gastrointestinal symptoms, those complaining of blood loss, those who abuse analgesics, and those who are vegetarians.

Senior Lecturer in Haematology,

C A J WARDROP

University of Wales College of Medicine,

Cardiff CF4 4XN

1 Davidson RJL, Robertson JD, Galea G, et al. Haematological changes associated with marathon running. Int f Sports Med 1987;8:19-25.

2 Anonymous. "Anaemia" in athletes [Editorial]. Lancet 1985; i: 1490-1.

3 Magnusson B, Hallberg L, Rossander L, Swolin B. Iron metabolism and 'sports anemia' I. Acta Med Scand 1984;216:149-55.

4 Magnusson B, Hallberg L, Rossander L, Swolin B. Iron metabolism and 'sports anemia' II. Acta Med Scand 1984;216:157-64.

5 Hunding A, Jordel R, Paulev PE. Runner's anemia and iron deficiency. Acta Med Scand 1985;209:315-8.

6 Brotherhood J, Brozovic B, Pugh LGC. Haematological status of middle and long distance runners. Clinical Science and Molecular Medicine 1975;48:139-45.

7 Hallberg L, Magnusson B. The etiology of 'sports anemia'. Acta Med Scand 1984;216:145-8.

8 Shappell SD, Murray JA, Bellingham A, Woodson RD, Detter JC, Lenfant C. Adaptation to exercise: role of hemoglobin affinity for oxygen and 2, 3 DPG. I Appl Physiol 1971;230:827-32.

9 Porter AMW. Do some marathon runners bleed into the gut? BrMed f 1983;287:1427.

10 Stewart JG, Ahlquist DA, McGill DB, Ilstrup DM, Schwartz S, Owen RA. Gastrointestinal blood loss and anemia in runners. Ann Intern Med 1984;100:843-5.

11 McMahon LF, Ryan MJ, Larson D, Fisher RL. Occult gastrointestinal blood loss in marathon runners. Ann Intem Med 1984;100:846-7.

runners. Ann Intern Med 1984;100:846-7.
12 Halvorsen FA, Lyng J, Ritland S. Gastrointestinal bleeding in marathon runners. Scan $\mathcal{J}$ Gastroenterol 1986;21:493-7.

13 Robertson JD, Maughan RJ, Davidson RJL. Faecal blood loss in response to exercise. Br Med $\mathcal{J}$ 1987;295:303-5.

14 Anonymous. CSM update. Non-steroidal anti-inflammatory drugs and serious gastrointestinal adverse reactions-1. BrMed $\mathcal{F}$ 1986;292:614.

\section{Benign testicular tumours}

Traditionally some $95 \%$ of solid testicular swellings are held to be malignant. Nevertheless, it has been suggested that benign testicular tumours may be more common than suspected, most of the patients reported having had granulomatous orchitis, tuberculosis, or epidermoid cysts. ${ }^{1}$ Is it really possible, then, to differentiate benign testicular swellings from malignant tumours preoperatively and avoid orchidectomy for benign disease?

Several features may raise the clinical suspicion of testicular malignancy. Three quarters of testicular cancers occur in those aged between 20 and $49^{2}$; almost a tenth occur in undescended testes, even after orchidopexy ${ }^{34}$; and one in 20 occur in patients who have a contralateral tumour. ${ }^{56}$ Testicular tumours are also commoner in patients who are infertile or have gonadal dysgenesis. ${ }^{78}$ Clinical investigations may not help in determining the nature of a solid swelling. Scrotal ultrasound is at least $80 \%$ accurate in showing the site of origin of a swelling in the scrotum ${ }^{9}$ but may not reliably tell us whether a swelling is malignant even if the testicular architecture is abnormal. Though raised concentrations of tumour markers in the serum (such as $\alpha$ fetoprotein and $\beta$ human chorionic gonadotrophin) suggest neoplasia, normal values do not exclude it.

Most surgeons have condemned needle biopsy of solid scrotal swellings because of the risk of tumour implantation. ${ }^{10}$ Usually the surgeon has to decide the fate of the testis at operation. All solid scrotal swellings in which malignancy cannot be excluded should be explored through an inguinal incision and the spermatic cord temporarily occluded before mobilisation of the testis: exploration through the scrotum is justified only if there is no suspicion of malignancy..$^{10}$ Between a quarter and a third of testicular tumours are erroneously explored through the scrotum, with the result that the inguinal, perineal, and pelvic regions may become infiltrated by a tumour, a development that is incurable with conventional treatment. ${ }^{10}$

Operative biopsy of the testis may also be unhelpful because of "sampling error," in which the tumour is not accessed; indeed, benign lesions may coexist in the testis with unrecognised malignant areas. ${ }^{11}$ Even splitting the testis into two (Chevassu's manoeuvre) may not help in identifying a benign tumour, though the procedure is useful when exploring a solitary testis. ${ }^{12}$ The only totally reliable method of excluding malignancy is to examine the entire testis histologically and this requires orchidectomy. Some urologists have gone on record as saying that orchidectomy is mandatory for all suspicious scrotal swellings and that there is no place for biopsy. ${ }^{13}$

Hence there is no reliable way to determine whether an intratesticular lesion is benign and can be enucleated without orchidectomy. The current trend towards improved screening and self examination of the genitalia means that surgeons will be faced with increasing numbers of undiagnosed scrotal swellings. ${ }^{14}$ Most of these patients will rightly be treated with inguinal orchidectomy, and inevitably testes will continue to be removed for benign disease. Some would regard this as a crime; the greater crime, however, is to leave behind a scrotal scar and a testis containing a malignant tumour.

Consultant Urologist,

Addenbrooke's Hospital,

Cambridge CB2 2QQ

1 Haas GP, Schumaker BP, Cerny JC. The high incidence of benign testicular tumours. $\mathcal{F}$ Urol 1986;136:1219-20.

2 Puch RCB. Testicular tumours-introduction. In: Pugh RCB, ed. Pathology of the testis. Oxford: Blackwell Scientific Publications, 1976:139-63.

3 Nilsson S, Anderström C, Hedelin H, Unsgaard B. Signs and symptoms of adult testicular tumours. In: Skakkebaek NE, Barthelsen JG, Grigor KM, Visfeldt J, eds. Early detection of testicular cancer. Copenhagen: Scriptor, 1981:146-52.

4 Batata MA, Whitmore WF, Chu FCH, et al. Cryptorchidism and testicular cancer. $f$ Urol 1980;124:382-7.

5 Berthelsen JG, Skakkebaek NE, Mogensen P, Sørensen BL. Incidence of carcinoma in situ of germ cells in contralateral testis of men with testicular tumours. BrMed f 1979;ii:363-4.

6 Hamilton JB, Gilbert JB. Studies in malignant tumors of the testis IV. Bilateral testicular cancer. Incidence, nature and bearing upon management of the patient with a single testicular cancer. Cancer Res 1942;2:125-9.

7 Skakkebaek NE, Bathelsen JG, Visfeldt J. Clinical aspects of testicular carcinoma-in-situ. In Skakkebaek NE, Barthelsen JG, Grigor KM, Visfeldt J, eds. Early detection of testicular cancer Copenhagen: Scriptor, 1981:153-62.

8 Hargreave TB. Carcinoma in situ of the testis. Br Med f 1986;293:1389-90.

9 Sample WF, Gottesman JE, Skinner DG, Ehrlich RM. Gray scale ultrasound of the scrotum. Radiology 1978;127:225-8.

10 Sigel A, Krieger F. Scrotal operation or biopsy of testicular tumours-a fatal mistake? In Grundmann E, Vahlensieck W, eds. Tumors of the male genital system. Berlin: Springer-Verlag, 1977:212-4.

11 Johnson JW, Hodge EE, Radwin HM. Epidermoid cyst of testis: a case for orchiectomy. Urolog 1987;29:23-5.

12 Hendry WF. Diagnosis and management of the primary testicular tumour. In: Peckham MJ, ed. The management of testicular tumours. London: Edward Arnold, 1981:83-8.

13 Blandy JP, Hope-Stone HF, Dayan AD. Tumours of the testicle. London: William Heinemann, 1970 .

14 Thornhill JA, Conroy RM, Kelly DG, Walsh A, Fennelly JJ, Fitzpatrick JM. Public awareness of testicular cancer and the valuc of self examination. BrMed $\mathcal{J}$ 1986;293:480-1. 